\title{
Response of Okra (Abelmoschus Esculentus l. Yalova Akköy-41) to Different Irrigation and Fertigation Levels
}

\author{
Serhat Ayas ${ }^{1, a, *}$ \\ *Corresponding author \\ Research Article \\ Received : 22/06/2020 \\ Accepted : 14/08/2020 \\ Keywords: \\ Irrigation \\ Fertigation \\ Yield and quality of okra \\ Okra cultivation \\ Bursa
}

${ }^{I}$ Yenisehir I.O. College, Uludag University, 16900 Yenisehir/Bursa, Turkey
A R T I C L I N F O A B S T R A T
This study was carried out in the greenhouses of Bursa Uludag University Yenişehir Ibrahim Orhan Vocational School in 2014-2015 to determine the effects of five different irrigation levels $\left(\mathrm{T}_{1}: 100 \%\right.$ (full irrigation), $\mathrm{T}_{2}: 75 \%, \mathrm{~T}_{3}: 50 \%, \mathrm{~T}_{4}: 25 \%, \mathrm{~T}_{5}: 0 \%$ (non-irrigated)) and two different fertilization levels $\left(\mathrm{F}_{1.0}: 100 \%\right.$ (100:100:100 NPK) fertigation and $\mathrm{F}_{0.5}: 50 \%$ (50:50:50 NPK) fertigation on yield and quality parameters of okra grown under unheated greenhouse conditions. In 2014 and 2015, the amount of irrigation water in the study was applied as $0.0-380.0 \mathrm{~mm}$ and $0.0-360.0 \mathrm{~mm}$ for the 100\% (100:100:100 NPK) fertilization and 50\% (50:50:50 NPK) fertilization treatments, respectively. Evapotranspiration values were realized as $200.0-410.0 \mathrm{~mm}$ and $130.0-400.0 \mathrm{~mm}$ for 100\% (100:100:100 NPK) and 50\% (50:50:50 NPK) fertilization treatments in 2014, 185.0-425.0 $\mathrm{mm}$ and $200.0-450.0 \mathrm{~mm}$ in 2015 , respectively. It was observed that irrigation water levels significantly affected the yield, fruit diameter, fruit length, 10 fruit weight, and number of fruits per plant and dry matter of okra. The highest yield averages for both years were obtained from $\mathrm{T}_{1} \mathrm{~F}_{1.0}$ and $\mathrm{T}_{1} \mathrm{~F}_{0.5}$ treatments were found to be 14.6-17.8 tons' $\mathrm{ha}^{-1}$ and 16.8 -15.7 tons' ha ${ }^{-1}$ in 2014 and 2015 , respectively. Crop response factors $\left(\mathrm{k}_{\mathrm{y}}\right)$ of okra were found as 1.38-1.26 and 1.26-1.41 for $100 \%$ (100:100:100 NPK) fertilization and 50\% (50:50:50 NPK) fertilization treatments in 2014 and 2015, respectively. The highest water use efficiency (WUE) and irrigation water use efficiency (IWUE) values were calculated as $0.036-0.038 \mathrm{~kg} \mathrm{~m}^{-3}$ and $0.045-0.049 \mathrm{~kg} \mathrm{~m}^{-3}$ from $\mathrm{T}_{1} \mathrm{~F}_{1.0}$ and $\mathrm{T}_{1} \mathrm{~F}_{0.5}$ treatments in 2014 and $0.040-0.047 \mathrm{~kg} \mathrm{~m}^{-3}$ and $0.035-0.046 \mathrm{~kg} \mathrm{~m}^{-3}$ from same treatments $\left(\mathrm{T}_{1} \mathrm{~F}_{1.0}\right.$ and $\mathrm{T}_{1} \mathrm{~F}_{0.5}$ ) in 2015 , respectively. The highest $\mathrm{T}_{1} \mathrm{~F}_{1.0}$ and $\mathrm{T}_{1} \mathrm{~F}_{0.5}$ values were the closest values were obtained from $\mathrm{T}_{2} \mathrm{~F}_{1.0}$ and $\mathrm{T}_{2} \mathrm{~F}_{0.5}$ treatments therefore $\mathrm{T}_{2} \mathrm{~F}_{1.0}$ and $\mathrm{T}_{2} \mathrm{~F}_{0.5}$ treatments can be recommended for okra.
(iD) http://orcid.org/0000-0002-9630-9699|

This work is licensed under Creative Commons Attribution 4.0 International License

\section{Introduction}

Okra production has an important place in world agriculture. Okra (Abelmoschus esculentus L. Moench), is an important vegetable crop, also known as lady's finger or bhendi belongs to family Malvaceae (Nagegowda et al., 2020). Okra productions in the world and in Turkey are 7 915533 tons and 51611 tons, respectively. Turkey is among the world ranks 30 th in 47 countries producing okra (TUIK, 2018). Okra is one of the important fruits produced in Marmara region of Turkey. In Bursa province of Marmara Region, annual okra production is about 887 tons of fruit from 240 ha (TUIK, 2016). While okra is produced as amateur in most of the regions of Turkey, it is cultivated as commercially in Aegean, Marmara, Mediterranean and Central Anatolian regions of the country and utilized freshly, frozen, dried and salted. Düzyaman (1997) states that okra cultures are spreading on the tropic, subtopical and Mediterranean climate belt. The countries that make commercial okra production are West African countries, Asian countries out of India and South East Asia, USA, Brazil, Australia and Turkey (Vural, 2000). Growing population and ever-increasing urbanization have intensely increased vegetable cultivation in peripheral urban areas. Therefore, it is essential to ensure a supply of quality vegetable seeds. Water and fertilizers, which are important inputs in agriculture, are the most important factors affecting yield. Therefore, applying the most efficient irrigation and fertilizer management is important in the crop production system (Nagegowda et al., 2020).

Water is more effective than other factors on the distribution and development of vegetation on earth. Vegetation develops very well in regions where rainfall is abundant and rainfall regime is good. The total amount of 
precipitation per region and its distribution by months is one of the most important factors that determine the plants growing in that region. The amount of water used by plants according to their development periods is also different. While plants consume less water in early development periods, they need the most water during flowering. The total water consumption of each plant variety is different. Total plant water consumption has a significant effect on yield (Falah and FehemYasir, 2020). Total plant water consumption increases as yield increases. Thus, the irrigation influences the quality and quantity of product in agriculture (Tonkaz et al., 2019). In recent years, with the increasing strategic importance of water, efforts have been increasing towards the rapid development of water resources. The first of these efforts is the application of irrigation techniques to save water (Gökmen, 2011). Irrigation planning is called as long as it determines how much irrigation water will be applied per irrigation and when to give water to the plant. An appropriate irrigation schedule should be planned for the efficient use of water, energy and fertilizer included in the production inputs (Nagegowda et al., 2020).

Most plant nutrients can be applied through irrigation systems. The application of nutrients with the irrigation system is called fertigation (Kaur et al., 2017). Application of $\mathrm{N}, \mathrm{P}$ and $\mathrm{K}$ with irrigation system can significantly increase yield by reducing the loss of nutrients. Macro elements are very important nutrients for plant growth and development. The formation of amino acids, nucleoproteins, amino sugars and other organic compounds in the plant occurs due to nitrogen. In addition, nitrogen contributes to all vital processes of the plant. In order for the plant cells perform well, various nitrogen components must be supplied to the plant. The two most important forms of nitrogen taken by plants are ammonium $\left(\mathrm{NH}_{4}{ }^{+}\right)$and nitrate $\left(\mathrm{NO}_{3}{ }^{-}\right)$ions (Kılıç and Korkmaz, 2012). In fertigation, the most appropriate nitrogen forms or nitrogen forms suitable for each plant should be researched and applied (Çetin and Tolay, 2009). Phosphorus plays a vital role in the formation of new cells and photosynthesis. Phosphorus is also a component of various nucleoproteins and lipids. In fertigation applications, phosphoric acid $\left(\mathrm{H}_{3} \mathrm{PO}_{4}\right)$ and ammonium phosphate fertilizers are widely used in the application of phosphorus fertilizers with drip irrigation systems (Çetin and Tolay, 2009). Fertigation of phosphorus with drip irrigation systems gives very effective results. Activator function in enzyme systems takes place thanks to potassium. It is known that potassium

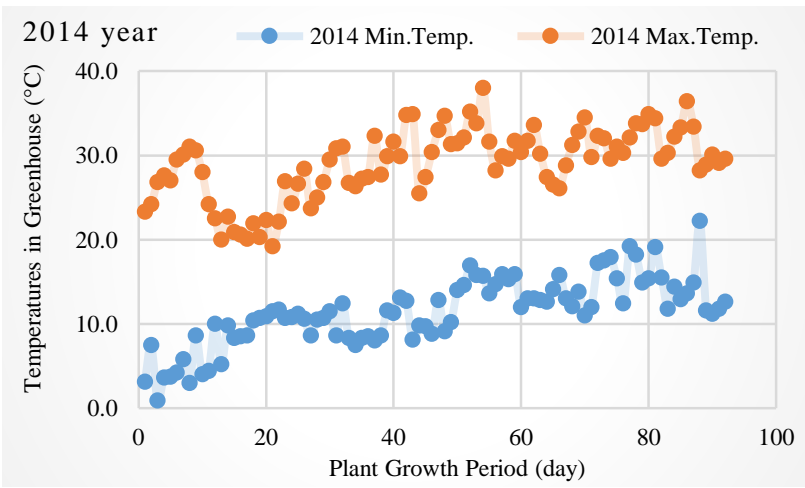

Figure 1. Temperatures in greenhouse during the plant growth period in 2014 contributes significantly to transpiration, respiration and water delivery in plant cells. It also promotes root division and development in plants. (Yazic1 ve Korkmaz, 2020). Potassium nitrate (KNO3) is used as a source of both $\mathrm{K}$ (potassium) and N (nitrogen) (Vijay, 2017).

Many studies have been carried out in the world and in Turkey on the irrigation of okras (Ünlükara et al., 2008; Ulu et al., 2016; Deveci et al., 2017; Ünlükara and Cemek, 2019). Previous studies have clearly shown that okra yield, fruit diameter, fruit length and 10 fruit weight, number of fruits per plant, and dry matter ratio are highly correlated with the amount of irrigation water. The previous studies on okra in Turkey were carried out in different irrigation levels. Unlike from previous studies, the effect of different fertigation levels as well as the different irrigation levels on okra were also investigated in our study. There are very few studies on okra related to the different fertigation levels as well as the different irrigation levels. The aim of this study is to determine the effect of different irrigation and fertigation levels on okra yield and some quality parameters.

\section{Materials and Methods}

The research was carried out in plastic covered greenhouse conditions in 2014 and 2015 years. BursaYenişehir region was chosen as the study area and $8 \times 40 \mathrm{~m}^{2}$ dimensional greenhouse was placed in the North-South direction. While the summer months are hot and dry, the winter months are cold and rainy in Yenişehir province. The average annual rainfall and temperature values for the region where the greenhouse experiments were made in 2014 and 2015 were $620.8-784.4 \mathrm{~mm}$ and $14.0-13.3^{\circ} \mathrm{C}$ respectively (Anonymous, 2011a). The maximum and minimum temperature values of greenhouse inner air in June-July-August months, which are considered as the plant growing period (92 days) were measured. Maximum and minimum temperature values were $38-38^{\circ} \mathrm{C}$ and 0.9 $3.3^{\circ} \mathrm{C}$, respectively in 2014-2015 years (Figure 1 and 2). The average relative humidity values for 2014 and 2015 were $75.8-76.8 \%$. The highest and lowest relative humidity values in greenhouse in 2014 and 2015 years were found as $88-87 \%$ and $39-40 \%$, respectively (Figure 3 ). In addition, the highest and lowest radiation values in greenhouse in 2014-2015 years were measured as 1974$1725 \mathrm{~W} / \mathrm{m}^{2}$ and $589-797 \mathrm{~W} / \mathrm{m}^{2}$, respectively (Figure. 4) (Anonymous, 2011b).

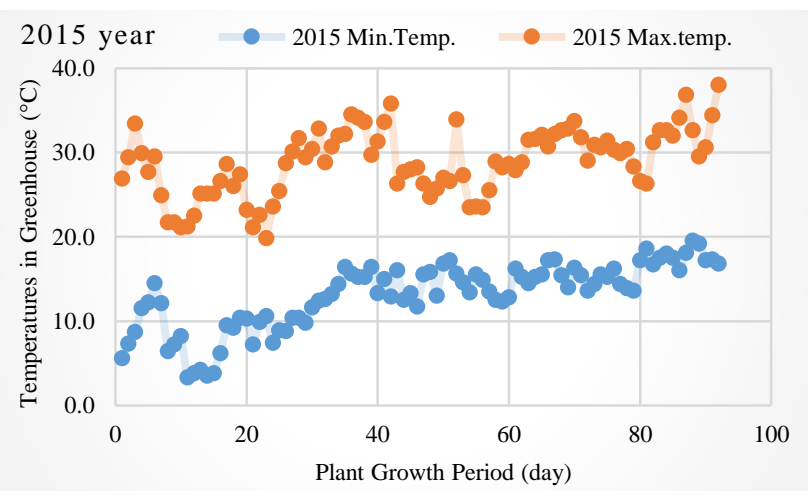

Figure 2. Temperatures in greenhouse during the plant growth period in 2015 

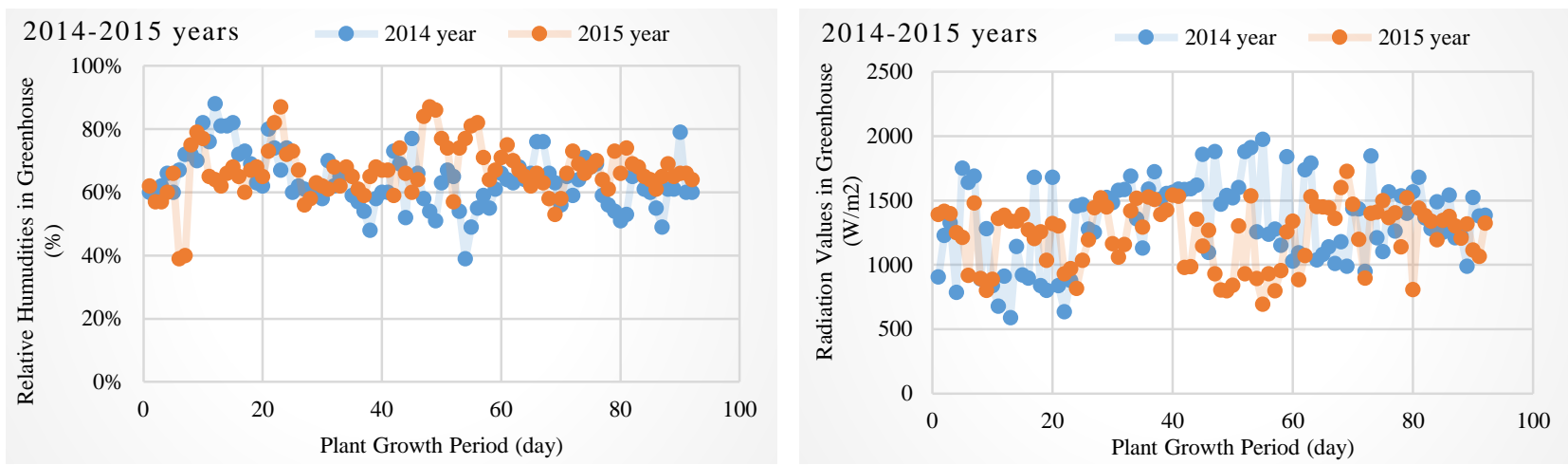

Figure 3. Relative humidities in greenhouse during the plant Figure 4. Radiation values in greenhouse during the plant growth period in 2014-2015 years growth period in 2014-2015 years

Table 1 Some specific properties of the experimental soil

\begin{tabular}{l|cccccccc}
\hline $\begin{array}{c}\text { Soil depth } \\
(\mathrm{cm})\end{array}$ & $\begin{array}{c}\text { Soil } \\
\text { type }\end{array}$ & $\begin{array}{c}\text { Unit weight } \\
\left(\mathrm{g} / \mathrm{cm}^{3}\right)\end{array}$ & $\begin{array}{c}\text { Field capacity } \\
(\%)\end{array}$ & $\begin{array}{c}\text { Wilting } \\
\text { point }(\%)\end{array}$ & $\mathrm{pH}$ & $\begin{array}{c}\text { Total salt } \\
(\%)\end{array}$ & $\begin{array}{c}\mathrm{CaCO}_{3} \\
(\%)\end{array}$ & $\begin{array}{c}\text { Organik } \\
\text { matter }(\%)\end{array}$ \\
\hline $0-30$ & SL & 1.35 & 31.37 & 23.47 & 8.01 & 0.043 & 17.8 & 3.10 \\
$30-60$ & SL & 1.38 & 28.86 & 20.88 & 8.24 & 0.037 & 31.5 & 1.54 \\
$60-90$ & SL & 1.60 & 35.29 & 25.76 & 7.90 & 0.038 & 32.8 & 1.17 \\
$90-120$ & SL & 1.54 & 37.65 & 28.86 & 8.08 & 0.035 & 35.6 & 0.98 \\
\hline SL-
\end{tabular}

SL: sandy loam

The soil of the trial site was sandy-clay and the soil reaction $(\mathrm{pH})$ value vary between 7.90 to 8.08 . Some of the physical and chemical properties of the soil of the experiment site are presented in Table 1.

Yalova Akköy-41 okra variety was developed with selective breeding of sultani type. Selection of this variety was completed in 1986 year. The fruits of the okra variety are bright green-yellowish and have a size of $0.8 \times 6.0 \mathrm{~cm}$. The fruits of this variety, which are of high quality, are also suitable making or selling canned food. The average yield of Yalova Akköy-41 variety is $1200 \mathrm{~kg}$ per decare. The estimated ripening period of the Yalova Akköy okra variety is $100-110$ days.

Mankozeb and Endosulfan were used as chemical drugs against okra diseases and insects. In addition, $101 \mathrm{ha}^{-1}$ chlorophyll-ethyl was sprayed against the insects. $100 \mathrm{~kg}$ ha $^{-1}$ potassium nitrate $\left(13 \% \mathrm{~N}\right.$ and $\left.46 \% \mathrm{~K}_{2} \mathrm{O}\right)$ and $100 \mathrm{~kg}$ ha $^{-1}$ phosphoric acid $\left(61 \% \mathrm{P}_{2} \mathrm{O}_{5}\right)$ in treatments which is applied as 100\% (100:100:100 NKP) fertigation as base dressing were applied to the soil two weeks before planting seedling process. In treatments which is applied as 50\% (50:50:50 NPK) fertigation were applied $50 \mathrm{~kg} \mathrm{ha}^{-1}$ potassium nitrate $\left(13 \% \mathrm{~N}\right.$ and $\left.46 \% \mathrm{~K}_{2} \mathrm{O}\right)$ and $50 \mathrm{~kg} \mathrm{ha}^{-1}$ phosphoric acid $\left(61 \% \mathrm{P}_{2} \mathrm{O}_{5}\right)$ as base dressing. $40 \mathrm{~kg} \mathrm{ha}^{-1}$ potassium nitrate $\left(13 \% \mathrm{~N}\right.$ and $\left.46 \% \mathrm{~K}_{2} \mathrm{O}\right)$ and $201 \mathrm{ha}^{-1}$ phosphoric acid $\left(61 \% \mathrm{P}_{2} \mathrm{O}_{5}\right)$ in treatments which is applied as \%100 (100:100:100 NPK) fertigation were applied to the soil six weeks after planting seedling process. In treatments which is applied as \%50 (50:50:50 NPK) fertigation were applied $20 \mathrm{~kg} \mathrm{ha}^{-1}$ potassium nitrate $(13 \%$ $\mathrm{N}$ and $\left.46 \% \mathrm{~K}_{2} \mathrm{O}\right)$ and $10 \mathrm{~kg} \mathrm{ha}^{-1}$ phosphoric acid $(61 \%$ $\left.\mathrm{P}_{2} \mathrm{O}_{5}\right) .50 \mathrm{~kg} \mathrm{ha}^{-1}$ potassium nitrate $\left(13 \% \mathrm{~N}\right.$ and $\left.46 \% \mathrm{~K}_{2} \mathrm{O}\right)$ and $201 \mathrm{ha}^{-1}$ phosphoric acid $\left(61 \% \mathrm{P}_{2} \mathrm{O}_{5}\right)$ in treatments which is applied as 100\% (100:100:100 NPK) fertigation were applied to the soil eight weeks after planting seedling process. In treatments which is applied as 50\% (50:50:50 NPK) fertigation were applied $25 \mathrm{~kg} \mathrm{ha}^{-1}$ potassium nitrate $\left(13 \% \mathrm{~N}\right.$ and $\left.46 \% \mathrm{~K}_{2} \mathrm{O}\right)$ and $10 \mathrm{~kg} \mathrm{ha}^{-1}$ phosphoric acid $\left(61 \% \mathrm{P}_{2} \mathrm{O}_{5}\right)$. In addition, $30 \mathrm{~kg} \mathrm{ha}^{-1}$ urea fertilizer (45\%$46 \% \mathrm{~N})$ which is applied as 100\% (100:100:100 NPK) fertigation and $15 \mathrm{~kg} \mathrm{ha}^{-1}$ urea fertilizer $(45 \%-46 \% \mathrm{~N})$ which is applied as 50\% (50:50:50 NPK) fertigation were applied to the soil. Potassium nitrate, phosphoric acid and urea fertilizer treatments were applied through the drip irrigation system.

Okra seedlings was planted on June 01 in 2014 and in 2015. The plant and row spacing applied in the experiment was $0.35 \mathrm{~m}$ and $0.35 \mathrm{~m}$, respectively. Each parcel involved 66 seedlings of okra. From the middle of each parcel were harvested 14 plants as sample plants, considering that water would leak from adjacent parcels. The fruit size of the okras taken as an example were measured with a calliper tool and the average values was measured. The dry matter ratio of the fruits was specified by drying the samples (at $65^{\circ} \mathrm{C}$ in a drying oven). The dry matter ratio was found by using (AOAC, 2000). The detail of the experimental plot is shown in Figure 5.

The experimental design was determined as a 3replicate and two-factor random block design. 5 different irrigation levels $\left(\mathrm{T}_{1}: 100 \%\right.$ (full irrigation), $\mathrm{T}_{2}: 75 \%, \mathrm{~T}_{3}$ : $50 \%, \mathrm{~T}_{4}: 25 \%, \mathrm{~T}_{5}: 0 \%$ (non-irrigated)) and two different fertilizer treatments $\left(\mathrm{F}_{1.0}: 100 \%\right.$ (100:100:100 NPK) fertigation and $\mathrm{F}_{0.5}: 50 \%$ (50:50:50) NPK) fertigation were distributed randomly to each block. All treatments are formed as follows: $\mathrm{T}_{1} \mathrm{~F}_{1.00}$ : $100 \%$ irrigation and $100 \%$ (100:100:100 NPK) fertigation, $\mathrm{T}_{2} \mathrm{~F}_{1.00}: 75 \%$ irrigation and 100\% (100:100:100 NPK) fertigation, $\mathrm{T}_{3} \mathrm{~F}_{1.00}: 50 \%$ irrigation and 100\% (100:100:100 NPK) fertigation, $\mathrm{T}_{4} \mathrm{~F}_{1.00}: 25 \%$ irrigation and 100\% (100:100:100 NPK) fertigation, $\mathrm{T}_{5} \mathrm{~F}_{1.00}$ : $0 \%$ irrigation and 100\% (100:100:100 NPK) fertigation, $\mathrm{T}_{1} \mathrm{~F}_{0.50}$ : (100\% irrigation and $50 \%$ (50:50:50 NPK) fertigation, $\mathrm{T}_{2} \mathrm{~F}_{0.50}: 75 \%$ irrigation and 50\% (50:50:50 NPK) fertigation, $\mathrm{T}_{3} \mathrm{~F}_{0.50}: 50 \%$ irrigation and $50 \%(50: 50: 50 \quad \mathrm{NPK})$ fertigation, $\mathrm{T}_{4} \mathrm{~F}_{0.50}: 25 \%$ irrigation and 50\% (50:50:50 NPK) fertigation application, $\mathrm{T}_{5} \mathrm{~F}_{0.50}$ : $0 \%$ irrigation and 50\% (50:50:50 NPK) fertigation. 


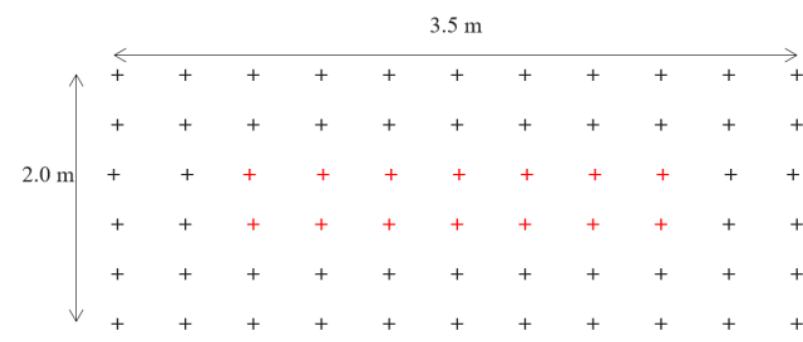

Figure 5. the detail of a plot

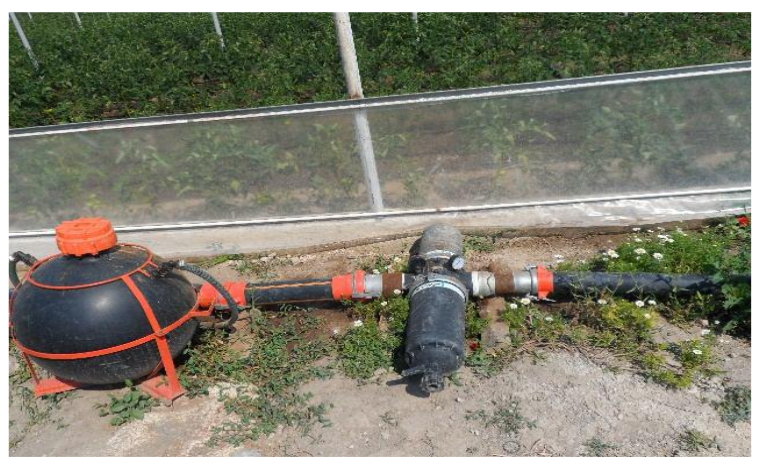

(a)

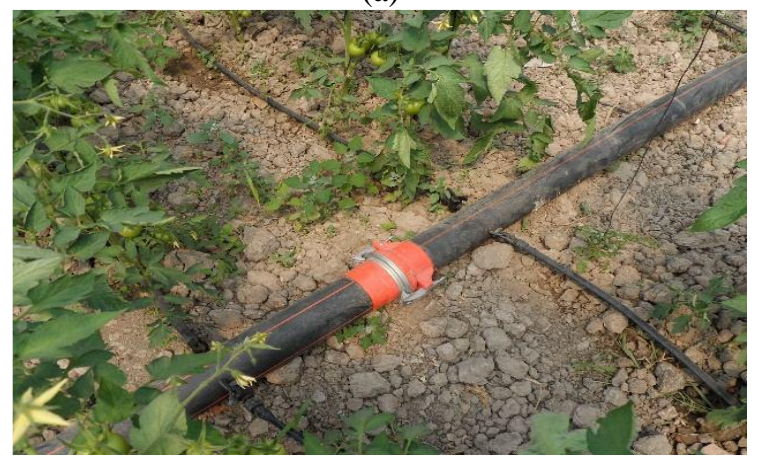

(b)

Figure 6 (a) Drip irrigation system, (b) Main and lateral pipes

Table 2. Specific properties of irrigation water

\begin{tabular}{c|c}
\hline Water source & Deep well \\
\hline $\mathrm{EC}_{25 \mathrm{x}\left(10^{6}\right)}$ & 723 \\
$\mathrm{Na}^{+}\left(\mathrm{me} \mathrm{L}^{-1}\right)$ & 2.5 \\
$\mathrm{~K}^{+}\left(\mathrm{me} \mathrm{L}^{-1}\right)$ & 2.67 \\
$\mathrm{Ca}^{2+}\left(\mathrm{me} \mathrm{L}^{-1}\right)$ & 9.55 \\
$\mathrm{Mg}^{2+}\left(\mathrm{me} \mathrm{L}^{-1}\right)$ & 5.8 \\
$\mathrm{pH}$ & 7.17 \\
Class & $\mathrm{C}_{2} \mathrm{~S}_{1}$ \\
SAR & 0.85 \\
\hline
\end{tabular}

The drip irrigation equipment in greenhouse used in the study was given in Figure 6.

Drip irrigation method was used in the trial. Irrigation water amount was calculated by placing flow measurement devices per parcel. The need for watering of the okra is provided by a deep well $\left(3 \mathrm{l} \mathrm{s}^{-1}\right)$ located in the greenhouse area. The depth of the well is 18 meters. Chemical composition of irrigation water were presented in Table-2. Groundwater composition of Yenişehir province is generally alkaline. The irrigation water applied in the experimental research was analysed and was determined to be in the $\mathrm{C}_{2} \mathrm{~S}_{1}$ class with low sodium risk and medium EC value. The water of the $\mathrm{C}_{2} \mathrm{~S}_{1}$ quality class has low sodium risk and medium electrical conductivity (EC). The irrigation of water of this quality class is used for plants with medium and highly salinity resistant. In addition, $\mathrm{C}_{2} \mathrm{~S}_{1}$ quality class water can be used in all plants and soils without creating a risk of alkalinity. $\mathrm{C}_{2} \mathrm{~S}_{1}$ quality class water was applied in a study on tomato plants (Ashraf and Ewees, 2008).

Soil moisture between $30-120 \mathrm{~cm}$ before and after irrigation was monitored by gravimetric method. Evapotranspiration (ET) was calculated by means of the water balance equation (Eq. 1).

$$
\mathrm{ET}=\mathrm{I}+\mathrm{P}-\mathrm{Rf}-\mathrm{Dp} \pm \Delta \mathrm{S}
$$

Where the evapotranspiration states with ET, the irrigation water amount is indicated by the I symbol, the total precipitation symbol is $\mathrm{P}$, the surface flow amount is $\mathrm{Rf}(\mathrm{mm})$, the deep drainage is shown by $\mathrm{Dp}(\mathrm{mm})$ and the soil water content at the beginning and end of the growth period states with $\mathrm{S}\left(\mathrm{mm} 120 \mathrm{~cm}^{-1}\right)$ symbol. Irrigation water was applied to the crop by the drip irrigation method before planting seedlings. Total precipitation $(\mathrm{P})$ and surface flow (Rf) were neglected in water requirements and consumption calculations in greenhouse. Soil water values in soil profiles deeper than $120 \mathrm{~cm}$ were accepted as deep drainage (Dp) and these values were neglected. The row spacing and intra row intervals in the experimental research were taken equally. Therefore, wetted area of dripper was calculated by the equation as follows (Eq. 2).

$$
P=\frac{S d}{S l} 100
$$

Where the percentage of wetted area states with $\mathrm{P}$, the interval of dripper and the intervals of lateral are indicated by $\mathrm{Sd}$ and $\mathrm{Sl}$ symbols, respectively. Irrigation water amount applied in each irrigation was obtained from the equation (Eq.3) given below.

$$
\mathrm{dn}=\frac{(\mathrm{FC}-\mathrm{WP}) R y}{100} \mathrm{yt} \mathrm{D} \frac{\mathrm{P}}{100}
$$

Where the amount of irrigation water applied in each irrigation states with dn, field capacity and wilting point are indicated by FC and WP, respectively. Soil bulk density, wetted soil depth and the percentage of wetted area are shown as $\mathrm{yt}, \mathrm{D}$ and $\mathrm{P}$, respectively. Steward Model (Eq.4) helps to describe the relationship between yield and ET in this experimental research (Stewart et al., 1975; Doorenbos and Kassam, 1979). The equation can be given as:

$$
\left(1-\frac{\mathrm{Ya}}{\mathrm{Ym}}\right)=\mathrm{ky}\left(1-\frac{\mathrm{ETa}}{\mathrm{ETm}}\right)
$$

Where the maximal and actual yield are shown as $\mathrm{Ym}$ $\left(\mathrm{t} \mathrm{ha} \mathrm{a}^{-1}\right.$ ) and $\mathrm{Ya}\left(\mathrm{t} \mathrm{ha} \mathrm{h}^{-1}\right)$, respectively. The maximal and actual evapotranspiration are shown as ETm (mm) and ETa $(\mathrm{mm})$, respectively. ky symbol states the yield response factor, the assessment of irrigation efficiency is determined by WUE values. WUE and IWUE terms contributes to the efficient use of irrigation water in plant production stages (Bos, 1980). By dividing the fruit yield into seasonal evapotranspiration (ET), WUE was calculated. IWUE was predicted as (Zhang et al., 1999): 


$$
\operatorname{IWUE}=\left(\frac{\mathrm{Y} 1-\mathrm{YN} 1}{\mathrm{I}}\right)
$$

Where the fruit yield of irrigated treatments $\left(\mathrm{t} \mathrm{ha}^{-1}\right)$, the fruit yield of non-irrigated $\left(\mathrm{t} \mathrm{ha} \mathrm{h}^{-1}\right)$ and the amount of irrigation water $(\mathrm{mm})$ are shown as $\mathrm{Y} 1$, YNI and I, respectively. Before the seedlings were plant into the greenhouse soil, the water content of the soil up $120 \mathrm{~cm}$ depth was calculated. Moisture level of the soil was completed to the level of field capacity in all treatments before starting irrigation. Irrigation was begun on June 08 in 2014 and in 2015 and it was repeated every 7 days.

Okras were harvested 92 days after planting in the greenhouse. The harvest of okra lasted 45 days. Yield and quality parameters of okras were analysed. By means of the LSD multiple comparison test $(\mathrm{P}<0.05)$, the variance analysis of the yield and quality parameters was evaluated. The values of yield productivity and quality parameters by using MSTAT-C and MINITAB software were analysed (Steel and Torrie, 1980).

\section{Results}

Before planting, each plots were given irrigation water to bring the soil moisture level up to field capacity (that is, 0-60 $\mathrm{cm}$ soil depth moisture level). After a week from planting okra seedlings, the first irrigation water treatment was applied. The maximum and minimum irrigation water amounts for 2014 and 2015 years were obtained from $\mathrm{T}_{1} \mathrm{~F}_{1.0}-\mathrm{T}_{1} \mathrm{~F}_{0.5}$ and $\mathrm{T}_{5} \mathrm{~F}_{1.0}-\mathrm{T}_{5} \mathrm{~F}_{0.5}$ treatments were $380-0 \mathrm{~mm}$ and $360-0 \mathrm{~mm}$, respectively. The amounts of other irrigation water applied during the experiment years ranged between 285-90 $\mathrm{mm}$ and 270-85 $\mathrm{mm}$, respectively. Seasonal evaporation $\left(\mathrm{ET}_{\mathrm{a}}\right)$ increased in parallel with the increase in the amount of applied irrigation water. The actual evapotranspiration values for $\mathrm{T}_{1} \mathrm{~F}_{1.0}-\mathrm{T}_{1} \mathrm{~F}_{0.5}$ and $\mathrm{T}_{5} \mathrm{~F}_{1.0}-\mathrm{T}_{5} \mathrm{~F}_{05}$ treatments in the first year varied between 410-400 $\mathrm{mm}$ and 200-130 $\mathrm{mm}$, respectively. These values in the second year varied between $400-450 \mathrm{~mm}$ and 130 $200 \mathrm{~mm}$, respectively (Tables 3, 4 and 5).

Table 3. Applied water and ET values according to irrigation and fertigation treatments in 2014 and 2015 years

\begin{tabular}{c|llrrrc}
\hline Fertilization & \multicolumn{1}{c}{$\mathrm{IT}$} & $\mathrm{T}$ & $\mathrm{AW} \mathrm{2014}$ & $\mathrm{AW} 2015$ & $\mathrm{CE} \mathrm{2014}$ & $\mathrm{CE} \mathrm{2015}$ \\
\hline \% 100 & $\mathrm{T}_{1}(\% 100)$ & $\mathrm{T}_{1} \mathrm{~F}_{1.0}$ & 380.0 & 360.0 & 410.0 & 425.0 \\
Fertilization & $\mathrm{T}_{2}(\% 75)$ & $\mathrm{T}_{2} \mathrm{~F}_{1.0}$ & 285.0 & 270.0 & 300.0 & 320.0 \\
$\left(\mathrm{~F}_{1.0}: \% 100\right.$ & $\mathrm{T}_{3}(\% 50)$ & $\mathrm{T}_{3} \mathrm{~F}_{1.0}$ & 190.0 & 200.0 & 250.0 & 235.0 \\
100:100:100 & $\mathrm{T}_{4}(\% 25)$ & $\mathrm{T}_{4} \mathrm{~F}_{1.0}$ & 95.0 & 90.0 & 210.0 & 210.0 \\
NPK) & $\mathrm{T}_{5}(\% 0)$ & $\mathrm{T}_{5} \mathrm{~F}_{1.0}$ & 0.0 & 0.0 & 200.0 & 185.0 \\
\hline$\% 50$ & $\mathrm{~T}_{1}(\% 100)$ & $\mathrm{T}_{1} \mathrm{~F}_{0.5}$ & 360.0 & 340.0 & 400.0 & 450.0 \\
Fertilization & $\mathrm{T}_{2}(\% 75)$ & $\mathrm{T}_{2} \mathrm{~F}_{0.5}$ & 270.0 & 260.0 & 280.0 & 320.0 \\
(F0.5: \%50 & $\mathrm{T}_{3}(\% 50)$ & $\mathrm{T}_{3} \mathrm{~F}_{0.5}$ & 180.0 & 170.0 & 250.0 & 300.0 \\
100:100:100 & $\mathrm{T}_{4}(\% 25)$ & $\mathrm{T}_{4} \mathrm{~F}_{0.5}$ & 90.0 & 85.0 & 150.0 & 220.0 \\
NPK) & $\mathrm{T}_{5}(\% 0)$ & $\mathrm{T}_{5} \mathrm{~F}_{0.5}$ & 0.0 & 0.0 & 130.0 & 200.0 \\
\hline
\end{tabular}

IT: Irrigation Treatments, T: Treatments, AW: Applied Water, CE: Crop Evapotranspiration

Table 4. Relationship between yield and yield response factor (ky) with the decrease in water use, for okra in 2014 year.

\begin{tabular}{l|cccccccc}
\hline Treatments & $\begin{array}{c}\text { Yield } \\
\left(\mathrm{t} \mathrm{ha}^{-1}\right)\end{array}$ & $\begin{array}{c}\text { Applied Water } \\
(\mathrm{mm})\end{array}$ & $\begin{array}{c}\mathrm{ETa} \\
(\mathrm{mm})\end{array}$ & ETa/ETm & Ya/Ym & 1-(ETa/ETm $)$ & 1-(Ya/Ym) & $\mathrm{k}_{\mathrm{y}}$ \\
\hline $\mathrm{T}_{1} \mathrm{~F}_{1.0}$ & 14.6 & 380.0 & 410.0 & 1.000 & 1.000 & 0.000 & 0.000 & 0.000 \\
$\mathrm{~T}_{2} \mathrm{~F}_{1.0}$ & 10.5 & 285.0 & 300.0 & 0.732 & 0.719 & 0.268 & 0.281 \\
$\mathrm{~T}_{3} \mathrm{~F}_{1.0}$ & 7.0 & 190.0 & 250.0 & 0.610 & 0.479 & 0.390 & 0.521 & 1.047 \\
$\mathrm{~T}_{4} \mathrm{~F}_{1.0}$ & 3.5 & 95.0 & 210.0 & 0.512 & 0.240 & 0.488 & 0.760 & 1.559 \\
$\mathrm{~T}_{5} \mathrm{~F}_{1.0}$ & 2.8 & 0.0 & 200.0 & 0.488 & 0.192 & 0.512 & 0.808 & 1.578 \\
$\mathrm{~T}_{1} \mathrm{~F}_{0.5}$ & 17.8 & 360.0 & 400.0 & 1.000 & 1.000 & 0.000 & 0.000 & 0.000 \\
$\mathrm{~T}_{2} \mathrm{~F}_{0.5}$ & 12.4 & 270.0 & 280.0 & 0.700 & 0.697 & 0.300 & 0.303 & 1.011 \\
$\mathrm{~T}_{3} \mathrm{~F}_{0.5}$ & 8.7 & 180.0 & 250.0 & 0.625 & 0.489 & 0.375 & 0.511 & 1.363 \\
$\mathrm{~T}_{4} \mathrm{~F}_{0.5}$ & 2.8 & 90.0 & 150.0 & 0.375 & 0.157 & 0.625 & 0.843 & 1.348 \\
$\mathrm{~T}_{5} \mathrm{~F}_{0.5}$ & 2.0 & 0.0 & 130.0 & 0.325 & 0.112 & 0.675 & 0.888 & 1.315 \\
\hline
\end{tabular}

Table 5. Relationship between yield and yield response factor (ky) with the decrease in water use, for okra in 2015 year.

\begin{tabular}{c|ccccccrc}
\hline Treatments & $\begin{array}{c}\text { Yield } \\
\left(\mathrm{t} \mathrm{ha}^{-1}\right)\end{array}$ & $\begin{array}{c}\text { Applied Water } \\
(\mathrm{mm})\end{array}$ & $\begin{array}{c}\mathrm{ETa} \\
(\mathrm{mm})\end{array}$ & ETa/ETm & Ya/Ym & 1-(ETa/ETm) & 1-(Ya/Ym) & $\mathrm{k}_{\mathrm{y}}$ \\
\hline $\mathrm{T}_{1} \mathrm{~F}_{1.0}$ & 16.8 & 360.0 & 425.0 & 1.000 & 1.000 & 0.000 & 0.000 & 0.000 \\
$\mathrm{~T}_{2} \mathrm{~F}_{1.0}$ & 12.6 & 270.0 & 320.0 & 0.753 & 0.750 & 0.247 & 0.250 & 1.012 \\
$\mathrm{~T}_{3} \mathrm{~F}_{1.0}$ & 9.2 & 200.0 & 235.0 & 0.553 & 0.548 & 0.447 & 0.452 & 1.012 \\
$\mathrm{~T}_{4} \mathrm{~F}_{1.0}$ & 4.0 & 90.0 & 210.0 & 0.494 & 0.238 & 0.506 & 0.762 & 1.506 \\
$\mathrm{~T}_{5} \mathrm{~F}_{1.0}$ & 2.4 & 0.0 & 185.0 & 0.435 & 0.143 & 0.565 & 0.857 & 1.518 \\
$\mathrm{~T}_{1} \mathrm{~F}_{0.5}$ & 15.7 & 340.0 & 450.0 & 1.000 & 1.000 & 0.000 & 0.000 & 0.000 \\
$\mathrm{~T}_{2} \mathrm{~F}_{0.5}$ & 11.3 & 260.0 & 320.0 & 0.711 & 0.720 & 0.289 & 0.280 & 0.970 \\
$\mathrm{~T}_{3} \mathrm{~F}_{0.5}$ & 7.7 & 170.0 & 300.0 & 0.667 & 0.490 & 0.333 & 0.510 & 1.529 \\
$\mathrm{~T}_{4} \mathrm{~F}_{0.5}$ & 3.0 & 85.0 & 220.0 & 0.489 & 0.191 & 0.511 & 0.809 & 1.583 \\
$\mathrm{~T}_{5} \mathrm{~F}_{0.5}$ & 1.8 & 0.0 & 200.0 & 0.444 & 0.115 & 0.556 & 0.885 & 1.594 \\
\hline
\end{tabular}



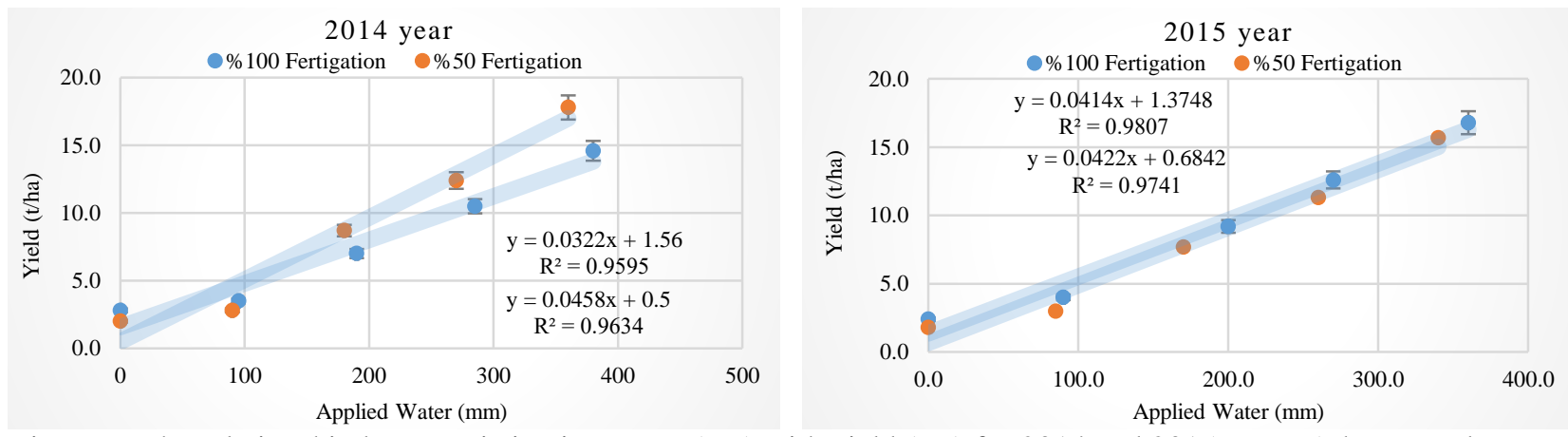

Figure 7. The relationship between irrigation water (IW) with yield (Ya) for 2014 and 2015 years. (The errors bars are SE of 14 plants)
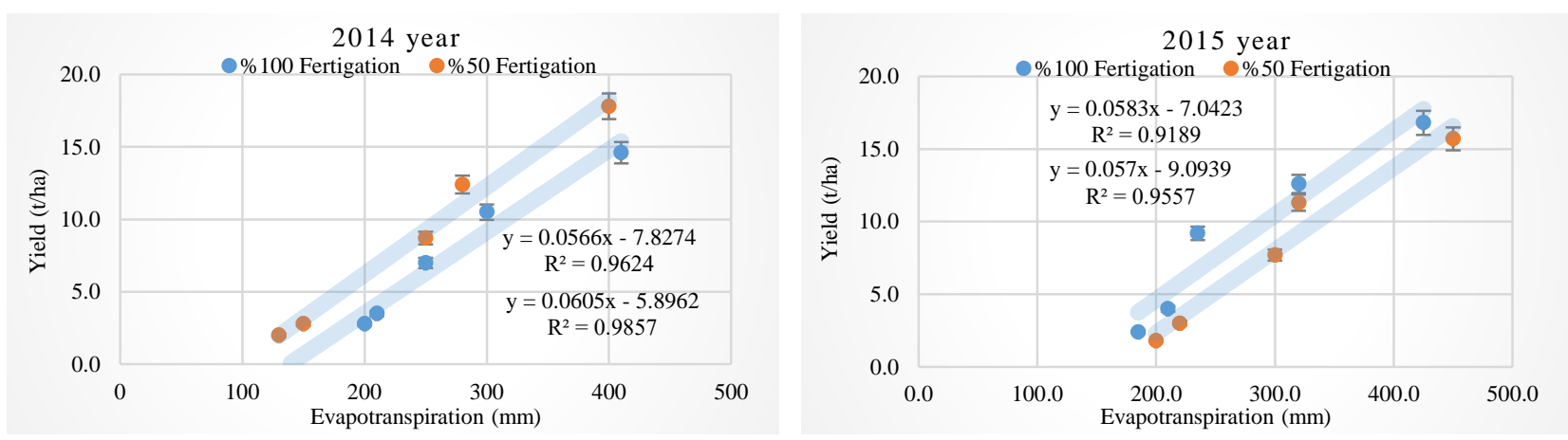

Figure 8. The relationship between ETc with yield (Ya) for 2014 and 2015 years. (The errors bars are SE of 14 plants)

Table 6. Effects of irrigation treatments on yield and quality parameters of okra in 2014 year.

\begin{tabular}{|c|c|c|c|c|c|c|c|}
\hline Fertilization & $\mathrm{T}$ & $\bar{Y}$ & $\overline{F L}$ & FD & FW & NFP & $\overline{D M}$ \\
\hline \multirow{5}{*}{$\begin{array}{c}\left(\mathrm{F}_{1.0}: \% 100\right. \\
100: 100: 100 \\
\text { NPK })\end{array}$} & $\mathrm{T}_{1} \mathrm{~F}_{1.0}$ & $14.6^{\mathrm{b}}$ & $7.2^{\mathrm{a}}$ & $1.5^{\mathrm{a}}$ & $55.0^{\mathrm{a}}$ & $15.0^{\mathrm{a}}$ & $7.0^{\mathrm{f}}$ \\
\hline & $\mathrm{T}_{2} \mathrm{~F}_{1.0}$ & $10.5^{\mathrm{d}}$ & $6.8^{\mathrm{b}}$ & $1.4^{\mathrm{ab}}$ & $42.0^{\mathrm{b}}$ & $14.6^{\mathrm{ab}}$ & $8.0^{\mathrm{e}}$ \\
\hline & $\mathrm{T}_{3} \mathrm{~F}_{1.0}$ & $7.0^{\mathrm{f}}$ & $5.8^{\mathrm{c}}$ & $1.2^{\mathrm{bcd}}$ & $30.0^{\mathrm{cd}}$ & $13.4^{\mathrm{abc}}$ & $9.5^{\mathrm{d}}$ \\
\hline & $\mathrm{T}_{4} \mathrm{~F}_{1.0}$ & $3.5^{\mathrm{g}}$ & $4.2^{\mathrm{e}}$ & $1.0^{\text {def }}$ & $27.0^{\mathrm{cd}}$ & $12.5^{\mathrm{c}}$ & $11.0^{\mathrm{c}}$ \\
\hline & $\mathrm{T}_{5} \mathrm{~F}_{1.0}$ & $2.8^{\mathrm{h}}$ & $3.6^{\mathrm{f}}$ & $0.8^{\mathrm{fg}}$ & $12.0^{\mathrm{e}}$ & $9.5^{\mathrm{e}}$ & $12.5^{\mathrm{ab}}$ \\
\hline Treatments & & $* *$ & $* *$ & $* *$ & $* *$ & $* *$ & $* *$ \\
\hline Blocks & & ns & ns & ns & ns & ns & ns \\
\hline \multirow{5}{*}{$\begin{array}{c}\left(\mathrm{F}_{0.5}: \% 50\right. \\
50: 50: 50 \\
\mathrm{NPK})\end{array}$} & $\mathrm{T}_{1} \mathrm{~F}_{0.5}$ & $17.8^{\mathrm{a}}$ & $7.1^{\mathrm{ab}}$ & $1.4^{\mathrm{ab}}$ & $58.0^{\mathrm{a}}$ & $14.5^{\mathrm{ab}}$ & $8.0^{\mathrm{e}}$ \\
\hline & $\mathrm{T}_{2} \mathrm{~F}_{0.5}$ & $12.4^{\mathrm{c}}$ & $6.9^{\mathrm{ab}}$ & $1.3^{\mathrm{abc}}$ & $44.0^{\mathrm{b}}$ & $14.2^{\mathrm{ab}}$ & $9.5^{\mathrm{d}}$ \\
\hline & $\mathrm{T}_{3} \mathrm{~F}_{0.5}$ & $8.7^{\mathrm{e}}$ & $6.0^{\mathrm{c}}$ & $1.1^{\mathrm{cde}}$ & $31.0^{\mathrm{c}}$ & $13.2^{\mathrm{bc}}$ & $10.5^{\mathrm{c}}$ \\
\hline & $\mathrm{T}_{4} \mathrm{~F}_{0.5}$ & $2.8^{\mathrm{h}}$ & $5.0^{\mathrm{d}}$ & $0.9^{\text {efg }}$ & $25.0^{\mathrm{d}}$ & $12.3^{\mathrm{cd}}$ & $12.0^{\mathrm{b}}$ \\
\hline & $\mathrm{T}_{5} \mathrm{~F}_{0.5}$ & $2.0^{1}$ & $4.2^{\mathrm{e}}$ & $0.7^{\mathrm{g}}$ & $14.0^{\mathrm{e}}$ & $10.8 \mathrm{~d}^{\mathrm{e}}$ & $13.0^{\mathrm{a}}$ \\
\hline Treatments & & $* *$ & $* *$ & $* *$ & $* *$ & $* *$ & $* *$ \\
\hline Blocks & & ns & ns & ns & ns & ns & ns \\
\hline
\end{tabular}

T: Treatments, Y: Yield $\left(\mathrm{t} \mathrm{ha}^{-1}\right)$, FL: Fruit Length (cm), FD: Fruit Diameter (cm), FW: 10 Fruit Weight (g), NFP: Number of Fruits Per Plant, DM: Dry Matter (\%)

Table 7. Effects of irrigation treatments on yield and quality parameters of okra in 2015 year.

\begin{tabular}{|c|c|c|c|c|c|c|c|}
\hline Fertilization & $\mathrm{T}$ & $\bar{Y}$ & $\mathrm{FL}$ & FD & FW & NFP & $\mathrm{DM}$ \\
\hline \multirow{5}{*}{$\begin{array}{c}\left(\mathrm{F}_{1.0}:\right. \\
\% 100 \\
100: 100: 100 \\
\text { NPK })\end{array}$} & $\mathrm{T}_{1} \mathrm{~F}_{1.0}$ & $16.8^{\mathrm{a}}$ & $7.0^{\mathrm{a}}$ & $1.6^{\mathrm{a}}$ & $60.0^{\mathrm{a}}$ & $14.0^{\mathrm{a}}$ & $8.5^{\mathrm{g}}$ \\
\hline & $\mathrm{T}_{2} \mathrm{~F}_{1.0}$ & $12.6^{\mathrm{c}}$ & $6.7^{\mathrm{a}}$ & $1.6^{\mathrm{a}}$ & $48.0^{\mathrm{b}}$ & $13.5^{\mathrm{ab}}$ & $10.0^{\mathrm{e}}$ \\
\hline & $\mathrm{T}_{3} \mathrm{~F}_{1.0}$ & $9.2^{\mathrm{e}}$ & $6.0^{\mathrm{b}}$ & $1.4^{\mathrm{ab}}$ & $40.0^{c}$ & $12.5^{\mathrm{bc}}$ & $11.0^{\mathrm{d}}$ \\
\hline & $\mathrm{T}_{4} \mathrm{~F}_{1.0}$ & $4.0^{\mathrm{g}}$ & $5.0^{\mathrm{c}}$ & $1.3^{\mathrm{abc}}$ & $29.0^{\mathrm{d}}$ & $11.5^{\mathrm{c}}$ & $11.5^{\mathrm{c}}$ \\
\hline & $\mathrm{T}_{5} \mathrm{~F}_{1.0}$ & $2.4^{1}$ & $4.2^{\mathrm{d}}$ & $1.0^{\mathrm{c}}$ & $15.0^{\mathrm{e}}$ & $10.0^{\mathrm{d}}$ & $13.0^{\mathrm{a}}$ \\
\hline Treatments & & $* *$ & $* *$ & $* *$ & $* *$ & $* *$ & $* *$ \\
\hline Blocks & & $\mathrm{ns}$ & $\mathrm{ns}$ & $\mathrm{ns}$ & $\mathrm{ns}$ & ns & ns \\
\hline \multirow{5}{*}{$\begin{array}{c}\left(\mathrm{F}_{0.5}: \% 50\right. \\
50: 50: 50 \\
\mathrm{NPK})\end{array}$} & $\mathrm{T}_{1} \mathrm{~F}_{0.5}$ & $15.7^{\mathrm{b}}$ & $6.9^{\mathrm{a}}$ & $1.5^{\mathrm{a}}$ & $58.0^{\mathrm{a}}$ & $13.5^{\mathrm{ab}}$ & $9.0^{f}$ \\
\hline & $\mathrm{T}_{2} \mathrm{~F}_{0.5}$ & $11.3^{\mathrm{d}}$ & $6.6^{\mathrm{a}}$ & $1.5^{\mathrm{a}}$ & $50.0^{\mathrm{b}}$ & $13.0^{\mathrm{ab}}$ & $10.0^{\mathrm{e}}$ \\
\hline & $\mathrm{T}_{3} \mathrm{~F}_{0.5}$ & $7.7^{\mathrm{f}}$ & $5.9^{\mathrm{b}}$ & $1.4^{\mathrm{ab}}$ & $42.0^{c}$ & $11.5^{\mathrm{c}}$ & $11.5^{\mathrm{c}}$ \\
\hline & $\mathrm{T}_{4} \mathrm{~F}_{0.5}$ & $3.0^{\mathrm{h}}$ & $5.0^{\mathrm{c}}$ & $1.3^{\mathrm{abc}}$ & $33.0^{\mathrm{d}}$ & $10.0^{\mathrm{d}}$ & $12.5^{\mathrm{b}}$ \\
\hline & $\mathrm{T}_{5} \mathrm{~F}_{0.5}$ & $1.8^{\mathrm{j}}$ & $3.9^{\mathrm{d}}$ & $1.1^{\mathrm{bc}}$ & $18.0^{\mathrm{e}}$ & $8.0^{\mathrm{e}}$ & $13.0^{\mathrm{a}}$ \\
\hline Treatments & & $* *$ & $* *$ & $* *$ & $* *$ & $* *$ & $* *$ \\
\hline Blocks & & ns & ns & ns & ns & ns & ns \\
\hline
\end{tabular}

T: Treatments, Y: Yield $\left(\mathrm{t} \mathrm{ha}^{-1}\right)$, FL: Fruit Length (cm), FD: Fruit Diameter (cm), FW: 10 Fruit Weight (g), NFP: Number of Fruits Per Plant, DM: Dry Matter (\%) 

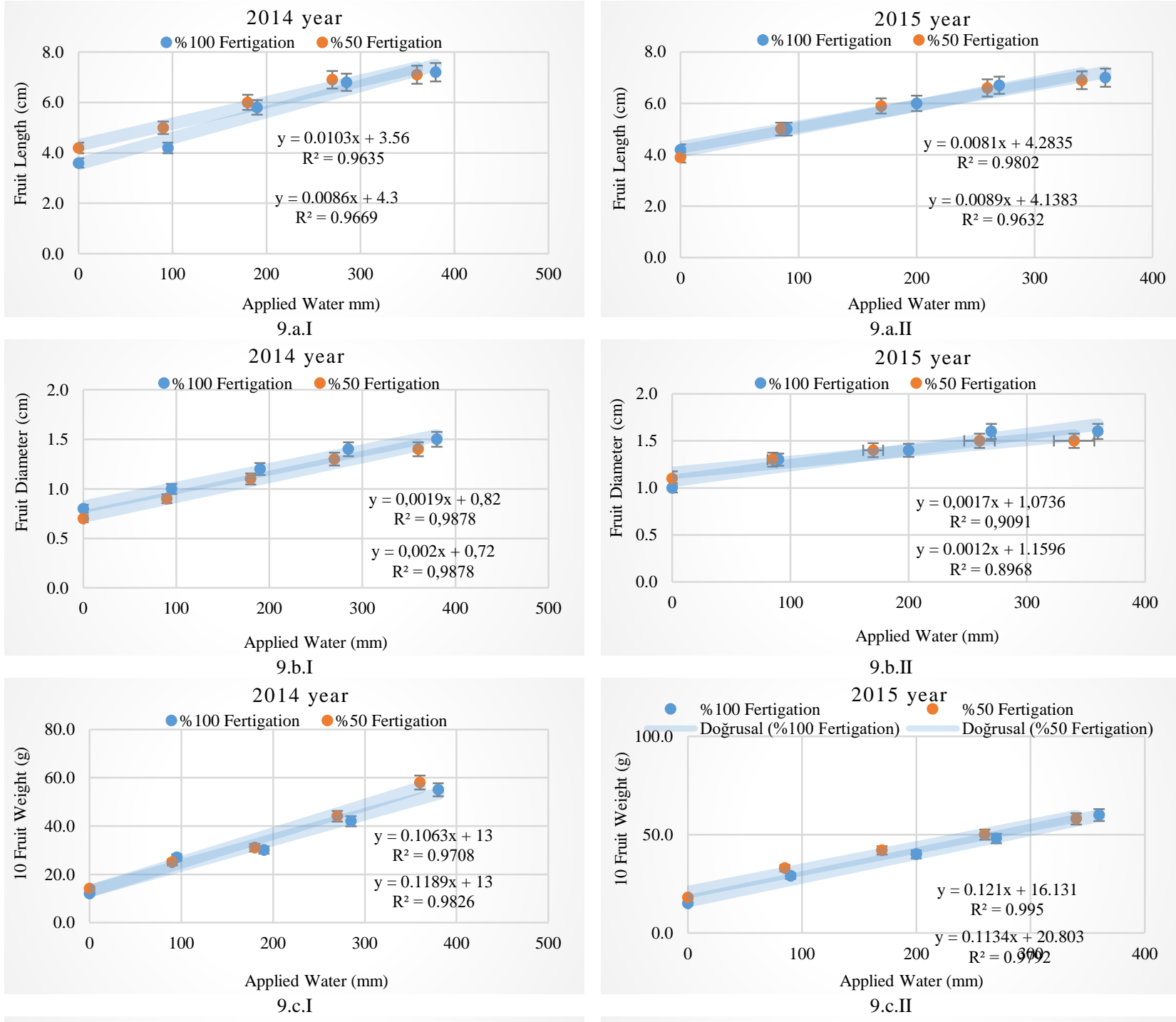

2014 year

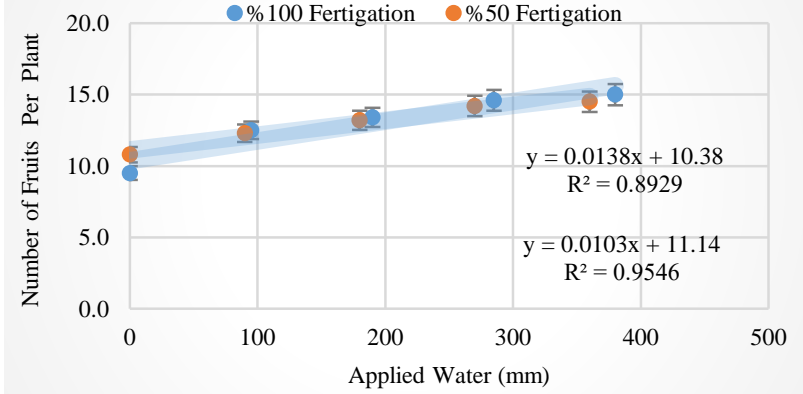

9.d.I

2014 year
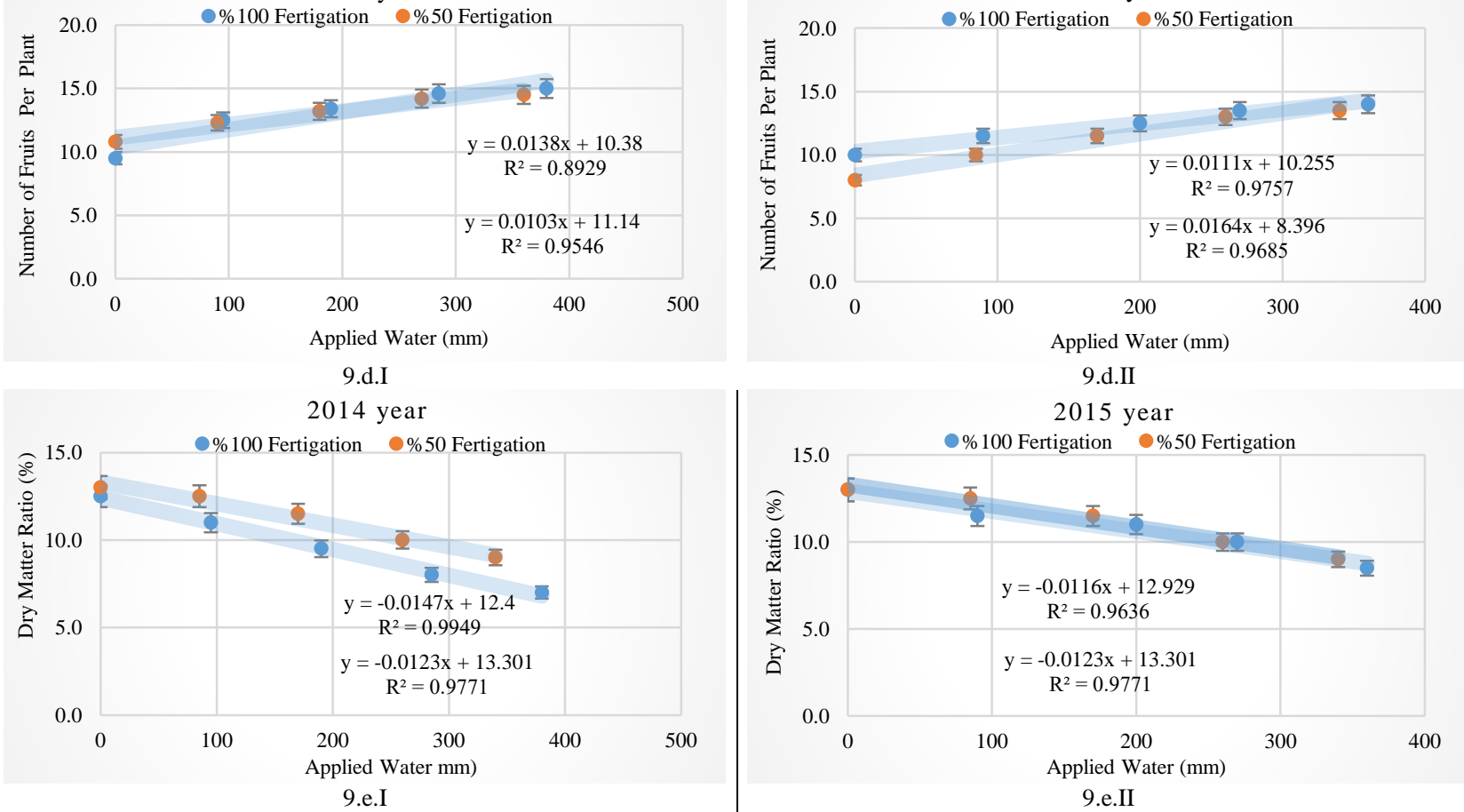

9.d.II

2015 year

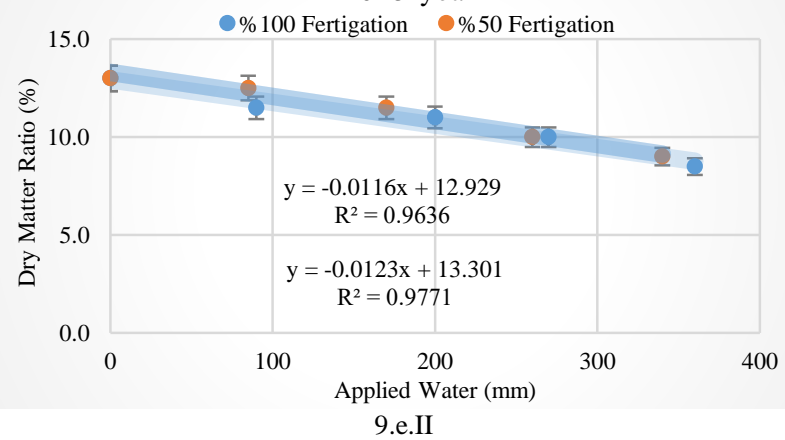

Figure 9. Relationship between applied of irrigation water and fruit length (a.I-a.II), diameter (b.I-b.II), 10 fruit weight (c.I-c.II), number of fruits per plant (d.I-d.II) and dry matter ratio (e.I-e.II). 
The highest yield values in treatments which is applied as $100 \%(100: 100: 100 \mathrm{NPK})$ fertigation and $50 \%$ (50:50:50 NPK) fertigation for the 2014-2015 years were obtained from $\mathrm{T}_{1} \mathrm{~F}_{1.0}$ and $\mathrm{T}_{1} \mathrm{~F}_{0.5}$ treatments and found as 14.6-17.8 $\mathrm{t} \mathrm{ha}^{-1}$ and 16.8-15.7 $\mathrm{t} \mathrm{ha}^{-1}$, respectively. $\mathrm{T}_{1} \mathrm{~F}_{1.0}$ treatments in both trial years were followed by $\mathrm{T}_{2} \mathrm{~F}_{1.0}$, $\mathrm{T}_{3} \mathrm{~F}_{1.0}, \mathrm{~T}_{4} \mathrm{~F}_{1.0}$ and $\mathrm{T}_{2} \mathrm{~F}_{0.5}, \mathrm{~T}_{3} \mathrm{~F}_{0.5}, \mathrm{~T}_{4} \mathrm{~F}_{0.5}$ treatments and yield values for 2014 and 2015 years were 10.5, 7.0, 3.5 - 12.4, 8.7, $2.8 \mathrm{t} \mathrm{ha}^{-1}$ and 12.6, 9.7, 4.0 - 11.3, 7.7, 3.0 t ha-1, respectively. As expected, minimum yield values for 2014 and 2015 years were found from control $\mathrm{T}_{5} \mathrm{~F}_{1.0}$ and $\mathrm{T}_{5} \mathrm{~F}_{0.5}$ treatments (2.8-2.0 and 2.4 - 1.8 $\left.\mathrm{tha}^{-1}\right)$, in which irrigation was not applied. During the 2014 and 2015 testing years, the product yield of the untreated $\mathrm{T}_{5} \mathrm{~F}_{1.0}$ and $\mathrm{T}_{5} \mathrm{~F}_{0.5}$ treatments were lower by $421.4-790.0 \%$ and $600.0-$ $772.2 .0 \%$ compared to the $\mathrm{T}_{1} \mathrm{~F}_{1.0}$ and $\mathrm{T}_{1} \mathrm{~F}_{0.5}$ treatments. In addition, compared to the first year $\mathrm{T}_{1} \mathrm{~F}_{1.0}$ and $\mathrm{T}_{1} \mathrm{~F}_{0.5}$ treatments, $\mathrm{T}_{2} \mathrm{~F}_{1.0}, \mathrm{~T}_{3} \mathrm{~F}_{1.0}, \mathrm{~T}_{4} \mathrm{~F}_{1.0}$ and $\mathrm{T}_{2} \mathrm{~F}_{0.5}, \mathrm{~T}_{3} \mathrm{~F}_{0.5}, \mathrm{~T}_{4} \mathrm{~F}_{0.5}$ treatments achieved $39.1 \%, 108.6 \%, 317.1 \%-43.6 \%$, $104.6 \%, 535.7 \%$ and $33.3 \%, 82.6 \%, 320.0 \%-38.9 \%$, $103.9 \%, 423.3 \%$, lower product yields in the second year, respectively. (Table 6 and 7). Yield and quality have been reduced due to water shortages.

In the first year of the experiment, all yield averages were affected by different deficit irrigation treatments and all treatments were found in a different statistical group. The quality parameters such as fruit length, fruit diameter, 10 fruit weight and number of fruits per plant were affected by deficit irrigation and each of the treatments were almost situated in a different statistical group. There was a negative linear relationship between dry matter and applied water (IW). The amount of dry matter decreases as the water content in the tuber increases.

In the second year of the experiment, all yield averages were affected by different deficit irrigation treatments and all treatments were found in a different statistical group. The fruit length and 10 fruit weight values were particularly affected by deficit irrigation and all treatments were situated in a different statistical group. The quality parameters such as fruit diameter and number of fruits per plant were affected by deficit irrigation and each of the treatments were almost situated in a different statistical group. There was a negative linear relationship between dry matter and applied water (IW). The amount of dry matter decreases as the water content in the tuber increases

\section{Crop Yield Response Factor $\left(k_{y}\right)$}

The linear relationship between the proportional reduction in water consumption and the proportional reduction in yield productivity is indicated by ky and reflects the response of product efficiency to the reduction of water consumption. That is, they explain the decline in product productivity related to the decrease in water consumption per unit (Stewart, 1975; Doorenbos and Kassam, 1979). $\mathrm{k}_{\mathrm{y}}$ in different irrigation and fertigation levels (100\% (100:100:100 NPK) fertigation and 50\% (50:50:50 NPK) fertigation levels for the 2014 and 2015 experimental years was calculated as 1.38-1.26 and 1.261.41, respectively (Fig. 10). Except $\mathrm{T}_{5} \mathrm{~F}_{1.0}$ and $\mathrm{T}_{5} \mathrm{~F}_{0.5}$ treatments, $\mathrm{k}_{\mathrm{y}}$ values increased parallel to the increase of water amount.
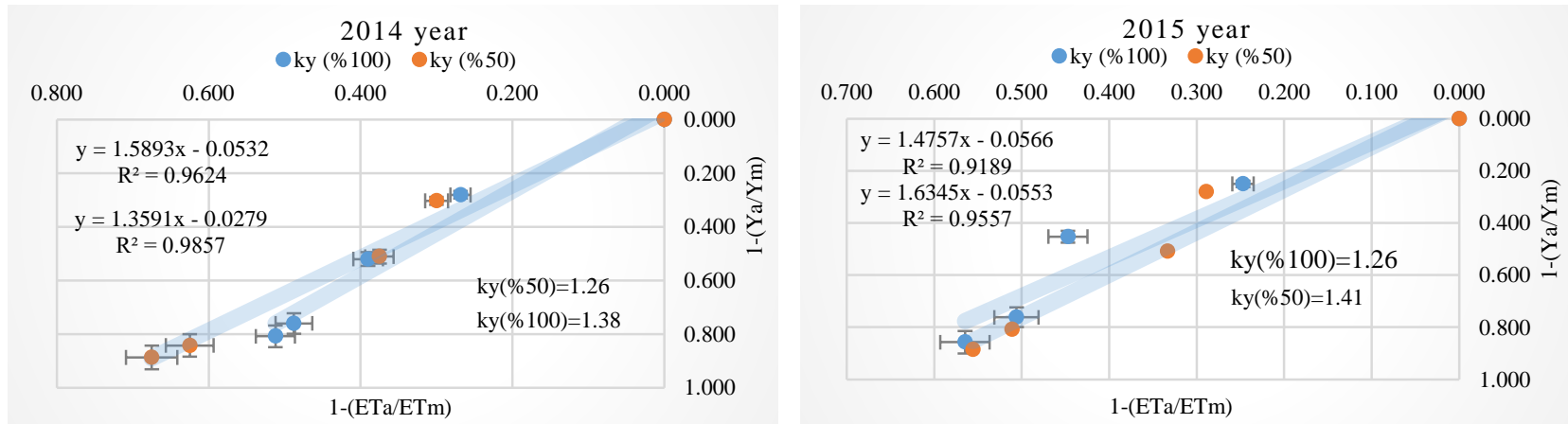

Figure 10. The relationship between relative yield decrease and relative evapotranspiration deficit for the experimental years (2014 and 2015)

Table 8. WUE and IWUE values for drip-irrigated okra at the treatments of different irrigation and fertigation levels for 2014 year.

\begin{tabular}{l|ccccc}
\hline \multicolumn{1}{c|}{ Treatments } & Yield $\left(\mathrm{t} \mathrm{ha}^{-1}\right)$ & Applied Water $(\mathrm{mm})$ & ETa $(\mathrm{mm})$ & WUE $\left(\mathrm{kg} \mathrm{m}^{-3}\right)$ & IWUE $\left(\mathrm{kg} \mathrm{m}^{-3}\right)$ \\
\hline $\mathrm{T}_{1} \mathrm{~F}_{1.0}$ & 14.6 & 380.0 & 410.0 & 0.036 & 0.038 \\
$\mathrm{~T}_{2} \mathrm{~F}_{1.0}$ & 10.5 & 285.0 & 300.0 & 0.035 & 0.037 \\
$\mathrm{~T}_{3} \mathrm{~F}_{1.0}$ & 7.0 & 190.0 & 250.0 & 0.028 & 0.037 \\
$\mathrm{~T}_{4} \mathrm{~F}_{1.0}$ & 3.5 & 95.0 & 210.0 & 0.017 & 0.037 \\
$\mathrm{~T}_{5} \mathrm{~F}_{1.0}$ & 2.8 & 0.0 & 200.0 & 0.014 & 0.000 \\
$\mathrm{~T}_{1} \mathrm{~F}_{0.5}$ & 17.8 & 360.0 & 400.0 & 0.045 & 0.049 \\
$\mathrm{~T}_{2} \mathrm{~F}_{0.5}$ & 12.4 & 270.0 & 280.0 & 0.044 & 0.046 \\
$\mathrm{~T}_{3} \mathrm{~F}_{0.5}$ & 8.7 & 180.0 & 250.0 & 0.035 & 0.048 \\
$\mathrm{~T}_{4} \mathrm{~F}_{0.5}$ & 2.8 & 90.0 & 150.0 & 0.019 & 0.031 \\
$\mathrm{~T}_{5} \mathrm{~F}_{0.5}$ & 2.0 & 0.0 & 130.0 & 0.015 & 0.000 \\
\hline
\end{tabular}


Table 9. WUE and IWUE values for drip-irrigated okra at the treatments of different irrigation and fertigation levels for 2015 year.

\begin{tabular}{l|ccccc}
\hline Treatments & Yield $\left(\mathrm{t} \mathrm{ha}^{-1}\right)$ & Applied Water $(\mathrm{mm})$ & ETa $(\mathrm{mm})$ & WUE $\left(\mathrm{kg} \mathrm{m}^{-3}\right)$ & IWUE $\left(\mathrm{kg} \mathrm{m}^{-3}\right)$ \\
\hline $\mathrm{T}_{1} \mathrm{~F}_{1.0}$ & 16.8 & 360.0 & 425.0 & 0.040 & 0.047 \\
$\mathrm{~T}_{2} \mathrm{~F}_{1.0}$ & 12.6 & 270.0 & 320.0 & 0.039 & 0.047 \\
$\mathrm{~T}_{3} \mathrm{~F}_{1.0}$ & 9.2 & 200.0 & 235.0 & 0.039 & 0.046 \\
$\mathrm{~T}_{4} \mathrm{~F}_{1.0}$ & 4.0 & 90.0 & 210.0 & 0.019 & 0.044 \\
$\mathrm{~T}_{5} \mathrm{~F}_{1.0}$ & 2.4 & 0.0 & 185.0 & 0.013 & 0.000 \\
$\mathrm{~T}_{1} \mathrm{~F}_{0.5}$ & 15.7 & 340.0 & 450.0 & 0.035 & 0.046 \\
$\mathrm{~T}_{2} \mathrm{~F}_{0.5}$ & 11.3 & 260.0 & 320.0 & 0.035 & 0.043 \\
$\mathrm{~T}_{3} \mathrm{~F}_{0.5}$ & 7.7 & 170.0 & 300.0 & 0.026 & 0.045 \\
$\mathrm{~T}_{4} \mathrm{~F}_{0.5}$ & 3.0 & 85.0 & 220.0 & 0.014 & 0.035 \\
$\mathrm{~T}_{5} \mathrm{~F}_{0.5}$ & 1.8 & 0.0 & 200.0 & 0.009 & 0.000 \\
\hline
\end{tabular}

\section{Water-Use Efficiency}

During the experimental years, when the irrigation water amount decreased, the WUE and IWUE values also decreased. The highest WUE values of both years were obtained from $\mathrm{T}_{1} \mathrm{~F}_{1.0}, \mathrm{~T}_{1} \mathrm{~F}_{0.5}, \mathrm{~T}_{2} \mathrm{~F}_{1.0}$ and $\mathrm{T}_{2} \mathrm{~F}_{0.5}$ treatments were calculated as $0.036,0.045,0.035,0.044-0.040,0.035$, $0.039,0.035 \mathrm{~kg} \mathrm{~m}^{-3}$, respectively. The highest IWUE values of both years were similarly obtained from $\mathrm{T}_{2} \mathrm{~F}_{1.0}$ and $\mathrm{T}_{2} \mathrm{~F}_{0.5}$ treatments and were calculated as $0.038,0.049,0.037,0.046$ $-0.047-0.046,0.047,0.043 \mathrm{~kg} \mathrm{~m}^{-3}$, respectively. The WUE and IWUE values of $\mathrm{T}_{1} \mathrm{~F}_{0.5}$ and $\mathrm{T}_{2} \mathrm{~F}_{0.5}$ treatments in 2014 were found to be higher than the other treatments such as $\mathrm{T}_{1} \mathrm{~F}_{1.0}, \mathrm{~T}_{2} \mathrm{~F}_{1.0}, \mathrm{~T}_{3} \mathrm{~F}_{1.0}, \mathrm{~T}_{4} \mathrm{~F}_{1.0}, \mathrm{~T}_{5} \mathrm{~F}_{1.0}$ and $\mathrm{T}_{2} \mathrm{~F}_{0.50}, \mathrm{~T}_{3} \mathrm{~F}_{0.5}, \mathrm{~T}_{4} \mathrm{~F}_{0.5}$, $\mathrm{T}_{5} \mathrm{~F}_{0.5}$, respectively. The WUE and IWUE values of $\mathrm{T}_{1} \mathrm{~F}_{1.0}$ treatment in 2015 were found to be higher than the other treatments such as $\mathrm{T}_{2} \mathrm{~F}_{1.0}, \mathrm{~T}_{3} \mathrm{~F}_{1.0}, \mathrm{~T}_{4} \mathrm{~F}_{1.0}, \mathrm{~T}_{5} \mathrm{~F}_{1.0}$ and $\mathrm{T}_{1} \mathrm{~F}_{0.50}$, $\mathrm{T}_{2} \mathrm{~F}_{0.5}, \mathrm{~T}_{3} \mathrm{~F}_{0.5}, \mathrm{~T}_{4} \mathrm{~F}_{0.5}, \mathrm{~T}_{5} \mathrm{~F}_{0.5}$ respectively (Table 8 and 9 ).

\section{Discussion}

In our study years, the amount of water applied ranged between $0.0-380.0 \mathrm{~mm}$ and $0.0-360.0 \mathrm{~mm}$ while the actual evapotranspiration ranged between $130.0-410.0$ $\mathrm{mm}$ and $185.0-450.0 \mathrm{~mm}$. Bahadur et al. (2009) reported that the total water applied for $\mathrm{I}_{1}, \mathrm{I}_{2}, \mathrm{I}_{3}$, and $\mathrm{I}_{4}$ were 628 , 575,255 and $180 \mathrm{~mm}$, respectively. In mulched plot, the estimated total water applied was $278, \mathrm{~mm}$ and $395 \mathrm{~mm}$ in "no mulch". Aliku and Oshunsanya (2016) reported that daily crop evapotranspiration values for DS1, DS2 and HF applications range from 1.16 to $3.36,1.17$ to 3.64 and 1.2 to $3.38 \mathrm{~mm} \mathrm{day}^{-1}$, respectively. Ünlükara and Cemek (2019) specified that the water consumption and fresh fruit production were found $664.0 \mathrm{~mm}$ and $28690 \mathrm{~kg} \mathrm{ha}^{-1}, 596.0$ $\mathrm{mm}$ and $24691.0 \mathrm{~kg} \mathrm{ha}^{-1}$ and $506.0 \mathrm{~mm}$ and $20554.0 \mathrm{~kg} \mathrm{ha}$ ${ }^{1}$ for I100, I75 and I50 treatments, respectively. Sharma and Kaushal (2015) determined that drip irrigation in okra saves $20 \%$ to $61 \%$ of water, increases yield by $13 \%$ to $76 \%$, fertilizer saving from $15 \%$ to $30 \%$ as compared with traditional method. Nagegowda et al., (2020) indicated that the application of water soluble fertilizer T4- 150:75:150 NPK kg ha-1 through fertigation either with mulch (14.05 q $\left.\mathrm{ha}^{-1}\right)$ or non-mulch $\left(11.83 \mathrm{q} \mathrm{ha}^{-1}\right)$ recorded significantly higher seed yield than fertilization through soil application $\left(9.92 \mathrm{q} \mathrm{ha}^{-1}\right)$. These results were consistent with water and water consumption values found from previous studies (Anu et al., 2014; Sharma and Kaushal 2015; Aliku and Oshunsanya, 2016; Sindhu et al., 2016; Deveci et al., 2017; Kadam et al., 2017; Adejumo et al., 2018; Ünlükara and Cemek, 2019; Nagegowda et al., 2020).
The okra yield for 2014-2015 trial years hanged between $8640.0-500.0 \mathrm{~kg} \mathrm{ha}^{-1}$ and $8320.0-900.0 \mathrm{~kg} \mathrm{ha}^{-1}$. According to the conclusions of this trial, it is observed that limited irrigation has an important effect on the yield of the fruit. This result is in agreement with (Soomro et al., 2012, Sharma et al., 2016; Ulu et al., 2016; Deveci et al., 2017; Ünlükara and Cemek, 2019; Nagegowda et al., 2020). Similar results were obtained in previous irrigation regimes (Sharma and Kaushal, 2015; Sharma et al., 2016; Deveci et al., 2017; Ünlükara and Cemek, 2019; Nagegowda et al., 2020). As the irrigation water amounts decreased, the yield decreased significantly as well. The quality parameters of okra showed a same reaction to limited irrigation as beheld in the yield. The whole irrigation applications had higher values than the $\mathrm{T}_{5} \mathrm{~F}_{1.0}$ and $\mathrm{T}_{5} \mathrm{~F}_{0.5}$ treatments in which water is not used. These values show similarities with (Haris et al., 2014; Deveci et al., 2017; Adejumo et al., 2018; dos Santos Farias et al., 2019). The fruit weight values of $T_{1} F_{1.0}$ and $\mathrm{T}_{1} \mathrm{~F}_{0.5}$ treatments were higher compared to other irrigation treatments. In years of the trial, the maximum dry matter rate was observed in $\mathrm{T}_{5} \mathrm{~F}_{1.0}$ and $\mathrm{T}_{5} \mathrm{~F}_{0.5}$ treatments, while the minimum dry matter rate was found from $\mathrm{T}_{1} \mathrm{~F}_{1.0}$ and $\mathrm{T}_{1} \mathrm{~F}_{0.5}$ applications. With the obtained data, it can be decided that with the decrease in irrigation water deficit, there will be significant increases in the amount of dry matter. These results are consistent with those of (Bahadur et al., 2009; Sharma et al., 2016; Deveci et al., 2017; Adejumo et al., 2018; dos Santos Farias et al., 2019).

The highest WUE and IWUE values for 2014 and 2015 years found as $0.036-0.045,0.040-0.035 \mathrm{~kg} \mathrm{~m}^{-3}$ and $0.038-$ 0.049, 0.047-0.046 kg m${ }^{-3}$, respectively. $\mathrm{T}_{1} \mathrm{~F}_{1.0}, \mathrm{~T}_{1} \mathrm{~F}_{0.5}$, $\mathrm{T}_{2} \mathrm{~F}_{1.0}$ and $\mathrm{T}_{2} \mathrm{~F}_{0.5}$ treatments have delivered the highest as WUE value. The results of water use efficiency were found to be similar when compared with the findings of different researchers (Soomro et al., 2012; Haris et al., 2014; Deveci et al., 2017; dos Santos Farias et al., 2019). Type of the okra, climate and soil structure affects the yield and quality values. This situation as explained by Davis et al., (2008), it can be said to result from variety and applied cultural practices handling under different climate and geographical conditions. The factor of $\mathrm{k}_{\mathrm{y}}$ for 2014 and 2015 year were calculated as 1.40 and 1.00 for okra, respectively. The factor of $\mathrm{k}_{\mathrm{y}}$ (1.40 and 1.00) which is equal and higher than 1.00 showed that okra was susceptible to water. The factor of $\mathrm{k}_{\mathrm{y}}$ also shows similarities with values found other researchers working on the same topic (Ünlükara et al., 2008; Jayapiratha et al., 2010). 


\section{Conclusions}

According to the results of the study, irrigation water were applied 380.0 and $360.0 \mathrm{~mm}$ in $\mathrm{T}_{1} \mathrm{~F}_{1.0}$ treatment in 2014 and 2015 years. The plant water consumptions of okra were determined as 410.0-400.0 $\mathrm{mm}$ and 325.0-450.0 $\mathrm{mm}$ for $\mathrm{T}_{1} \mathrm{~F}_{1.0}$ and $\mathrm{T}_{1} \mathrm{~F}_{0.5}$ treatments in 2014 and 2015 years. The factors of $\mathrm{k}_{\mathrm{y}}$ for the different treatments $\left(\mathrm{T}_{1} \mathrm{~F}_{1.0}\right.$ and $\mathrm{T}_{1} \mathrm{~F}_{0.5}$ treatments) in 2014 and 2015 years were calculated as 1.38-1.26 and 1.26-1.41 for okra, respectively. The factors of $\mathrm{k}_{\mathrm{y}}$ (1.38-1.26 and 1.26-1.41) values are bigger than 1.00 showed that the okra was susceptible to water. The highest yield decreases in all treatments were in $\mathrm{T}_{5} \mathrm{~F}_{1.0}$ and $\mathrm{T}_{5} \mathrm{~F}_{0.5}$ treatments, while the lowest yield decreases were in $T_{1} F_{1.0}$ and $T_{1} F_{0.5}$ treatments. In our study, it was studied out that irrigation treatments considerable influences yield, fruit length, 10 fruit weight, fruit diameter, number of fruits per plant and dry matter ratio.

In this study, it was studied out that irrigation applications considerably influences yield, 10 fruit weight, fruit diameter, fruit length, number of fruits per plant and dry matter. In both years of the study, the highest yields were 14.6-17.8 $\mathrm{t} \mathrm{h}^{-1}$ and 16.8-15.7 $\mathrm{t} \mathrm{h}^{-1}$ and it was observed in $\mathrm{T}_{1} \mathrm{~F}_{1.0}$ and $\mathrm{T}_{1} \mathrm{~F}_{0.5}$ treatments. The lowest yield was observed as 2.8-2.0 $\mathrm{t} \mathrm{h}^{-1}$ and 2.4-1.8 $\mathrm{t} \mathrm{h}^{-1}$ in $\mathrm{T}_{5} \mathrm{~F}_{1.0}$ and $\mathrm{T}_{5} \mathrm{~F}_{0.5}$ treatments. Yield decreased considerably as a result of the diminishment in the water amount. It is necessary to carefully plan different irrigation and fertigation levels in arid or semi-arid regions where precipitation is insufficient. However, it is possible to say that different irrigation and fertigation levels and timing are significantly effective on okra yield. If a different irrigation and fertigation levels is obligatory, water deficiency should be planned only for $\mathrm{T}_{2} \mathrm{~F}_{1.0}$ and $\mathrm{T}_{2} \mathrm{~F}_{0.5}$ treatments of okra. Compared with other treatments, it seems more reasonable to apply different irrigation and fertigation levels in these two treatments. It can be recommended that $\mathrm{T}_{2} \mathrm{~F}_{1.0}$ and $\mathrm{T}_{2} \mathrm{~F}_{0.5}$ treatments are most suitable periods for the different irrigation and fertigation levels practices for okra irrigation by drip irrigation.

\section{References}

Adejumo SA, Ezeh OS, Mur LAJ. 2018. Okra growth and drought tolerance when exposed to water regimes at different growth stages Int. J. Veg. Sci. (2018), pp. 1-33

Aliku OO, Oshunsanya SO. 2016. Modelling irrigation water requirements at Physiological growth stages of okra life cycle using CROPWAT model for derived savunnah and humid forest zones of Nigeria. Agricultura Tropica Et Subtropica 49/1-4, 20-29.

Anonymous. 2011a. The Annual report of Meteorological Station, Bursa, Turkey. www.mgm.gov.tr/verideğerlendirme/il-ve-ilcelerstatistic.aspx?k

Anonymous. 2011b. The Meteorological Station of Greenhouse Application Area, Yenişehir-Bursa, Turkey. www.mgm.gov.tr/verideğerlendirme/il-ve-ilcelerstatistic.aspx?k

Anu V, Menon JS and Mathew EK. 2014. Effect of fertigation levels and drip system layout on performance of okra under plastic mulch. J. Agril. Engg, 2014;51 (4): 28-32.

AOAC (Association of Official Analytical Chemistry). 2000 Official methods of analysis, 17th ed. AOAC, Washington, DC, USA.
Ashraf SO, Ewees MSA. 2008. The possible use of humic acid incorporated with drip irrigation system to alleviate the harmful effects of saline water on tomato plants. - Fayoum J. Agric. Res. \& Dev. 22(1).

Bahadur A, Singh KP, RAI A, Verma A, RAI M. 2009. Physiological and yield response of okra (Abelmoschus esculentus) to irrigation scheduling and organic mulching. Indian Journal of Agricultural Sciences 79(10): 813-15.

Bos MG 1980. Irrigation efficiencies at crop production level. ICID Bull.29: 18-25.

Çetin Ö, Tolay İ. 2009. Fertigation Book (Hasad Publishing), Istanbul/Turkey. www.hasad.com.tr.

Davis AR, Webber CL, Perkins-Veazie P, Ruso V, Lopez Galarza S, Sakata Y. 2008. A Review of production systems on watermelon quality. Roceedings of the IXth EUCARPIA Meeting on 98 Genetics and Breeding of Cucurbitaceae (M. PITRAT, editor), INRA, Avignon, France, 515-520.

Deveci M, Cabi E, Arın L, Yavaş Ö. 2017. The effect of water on some physiological properties of Abelmoschus esculentus (L.) Moench cv. "Sultani". Journal of Tekirdağ Agricultural Faculty, The Special Issue of $2^{\text {nd }}$ International Balkan Agriculture Congress May 16-18.

Doorenbos J, Kassam AH. 1979. Yield response to water. FAO Irrigation and Drainage Paper No. 33, Rome.

Dos Santos Farias DB, da Silva PSO, Lucas AAT, de Freitas MI, de Jesus Santos T, Fontes PTN, de Oliveira Júnior LFG. 2019. Physiological and productive parameters of the okra under irrigation levels Sci. Hortic., 252 (2019), pp. 1-6

Düzyaman E. 1997. Research on yield, yield components and quality characteristics of hybrids and parents in some domestic and foreign okra genotypes. (Doctoral Thesis) Institute of Science of Ege University, Bornova-İzmir.

Falah JA, Fahem Yasir N. 2020. The effects of irrigation periods and spraying of humic acids on the growth and production of okra under protected agriculture conditions. Plant Archives, Vol. 20 No.1, pp.150-154.

Gökmen S. 2011. General ecology. Nobel Academic Publishing, ISBN: 6055426361, Turkey.

Haris AA, Kumar S, Singh AK, Rajan K. 2014. Drip irrigation scheduling in okra (Abelmoschus Esculentus L. Moench). HortFlora Research Spectrum, 3(3):274-277.

Jayapiratha V, Thushyanthy M, Sivakumar S. 2010. Performance evaluation of okra (Abelmoschus esculentus) under drip irrigation system. Asian Journal of Agricultural Research, Vol.4, No.3, pp.139-147.

Kadam DB, Kasture MC, Dodake SB, Dhopavkar RV and Dademal AA. 2017. Effect of boron and Konkanannapurna briquettes on yield, nitrogen use efficiency and nutrient uptake by okra (Abelmoschusesculentus(L.) IJCS, 2017: 5(3): 214-217.

Kaur R, Singh SK, Raturi HC. 2017. Effect of different levels of fertigation and foliar application of nutrients on capsicum (Capsicum annuum L. var. grossum) grown in soilless media under polyhouse conditions. Journal of Pharmacognosy and Phytochemistry, 6(6), 1770-1773.

Kılıç R, Korkmaz K. 2012. Kimyasal gübrelerin tarım topraklarında artık etkileri. Research Journal of Biology Sciences, 5(2), 87-90.

Nagegowda NS, Shankar Hebbar S, Shilpashree VM. 2020. Performance of mulching and fertigation on nutrient uptake and nutrient use efficiency in okra (Abelmoschus Esculentus L. Moench) for seed production. Current Agriculture Research Journal, Vol. 8, No. (1): 25-29.

Sharma P, Kaushal A. 2015. Growing okra with drip fertigationa review. Inter. J. Engg. Sci. Inven., 4(9): 2319 - 6734.

Sharma P, Kaushal A, Singh A, Garg S. 2016. Growth and yield attributes of okra under influence of drip irrigation. Int. Journal of Engineering Research and Applications. Vol:6, Issue: 2, Part 5, pp.85-91. 
Sindhu RKe, Vishal P. 2016. Evidências fitoquímicas, nutricionais e farmacológicas de Abelmoschus esculentus (L.). J. Phytopharmacol. 5 (6), 238-241.

Soomro KB, Sahito HA, Rind JA, MAL B, Kaleri SH. 2012. Effect of marginal quality water on okra, Abelmoschus Esculentus I. yield under drip irrigation system. Global Advanced Research Journal of Engineering, Technologh and Innovation, Vol 1(5):103-112.

Steel RGD, Torrie JH 1980. Principles and procedures of statistics. A biometrical approach. McGraw-Hill, NewYork, pp.186-187.

Stewart JI, Misra RD, Pruitt WO, Hagan RM. 1975. Irrigating corn and sorghum with a deficient water supply. Trans. ASAE, 18: 270-280.

Tonkaz T, Şahin S, Bostan SZ, Korkmaz K. 2019. Effect of supplementary irrigation on total antioxidant capacity and phenolic content of hazelnut. The Journal of Academic Agriculture, (special issue) Vol.8: 79-84.

TUIK. 2016. http://www.tuik.gov.tr/PreTablo.do?alt_id=1001
TUIK. 2018. http://www.tuik.gov.tr/PreTablo.do?alt_id=1001

Ulu Ö, Engindeniz S, Özden A. 2016. The Analysis of input usage efficiency in okra production in İzmir. Turkish Journal Agricultural Economics 22(2): 69-76.

Ünlükara A, Kurunç A, Kesmez GD, Yurtseven E. 2008. Growth and evapotranspiration of okra (Abelmoschus Esculentus L.) a influenced by salinity of irrigation water. Journal of irrigation and Drainage Engineering 134(2):160-166.

Ünlükara A and Cemek B. 2019. Response of okra to water stress. Mustafa Kemal University Journal of Agricultural Sciences 24(Special Issue): 313-319.

Vural H. 2000. The Department of Horticulture, Faculty of Agriculture, Ege University, Bornova-İzmir.

Yazici D and Korkmaz K. 2020. The effect of potassium applications on toxicity and uptake of boron in buckwheat. Akademik Ziraat Dergisi, 9(1), 151-162.

Zhang H, Wang X, You M, Liu C. 1999. Water-yield relations and water-use efficiency of winter wheat in the North China Plain. - Irrigation Science 19: 37-45. 